\title{
Melatonin promotes Schwann cell dedifferentiation and proliferation through the Ras/Raf/ERK and MAPK pathways, and glial cell-derived neurotrophic factor expression
}

\author{
YEE LIAN TIONG ${ }^{1}$, KHUEN YEN NG $^{2}$, RHUN YIAN KOH $^{3}$, GNANAJOTHY PONNUDURAI $^{4}$ and SOI MOI CHYE ${ }^{3}$ \\ ${ }^{1}$ School of Postgraduate, International Medical University, Kuala Lumpur 57000; \\ ${ }^{2}$ School of Pharmacy, Monash University Malaysia, Subang Jaya, Selangor 47500; \\ ${ }^{3}$ School of Health Science; ${ }^{4}$ School of Medicine, International Medical University, Kuala Lumpur 57000, Malaysia
}

Received September 6, 2018; Accepted November 22, 2019

DOI: $10.3892 /$ etm.2020.9143

\begin{abstract}
Upon peripheral nerve injury (PNI), continuous proliferation of Schwann cells is critical for axon regeneration and tubular reconstruction for nerve regeneration. Melatonin is a hormone that is able to induce proliferation in various cell types. In the present study, the effects of melatonin on promoting Schwann cell proliferation and the molecular mechanism involved were investigated. The present results showed that melatonin enhanced the melatonin receptors (MT1 and MT2) expression in Schwann cells. Melatonin induced Schwann cell dedifferentiation into progenitor-like Schwann cells, as observed by immunofluorescence staining, which showed Sox 2 marker expression. In addition, melatonin enhanced Schwann cell proliferation, mediated by the upregulation of glial cell-derived neurotropic factor (GNDF) and protein kinase $\mathrm{C}$ (PKC). Furthermore, the Ras/Raf/ERK and MAPK signaling pathways were also involved in Schwann cell dedifferentiation and proliferation. In conclusion, melatonin induced Schwann cell dedifferentiation and proliferation via the Ras/Raf/ERK, MAPK and GDNF/PKC pathways. The present results suggested that melatonin could be used to enhance the recovery of PNI.
\end{abstract}

\section{Introduction}

Peripheral nerve injury (PNI) is a common injury that can impact the quality of life of individuals (1). After an injury, peripheral axons activate the intrinsic growth capacity in the neuronal cell body and promote axonal regeneration (2).

Correspondence to: Dr Soi Moi Chye, School of Health Science, International Medical University, 126 Jalan Jalil Perkasa, 19 Bukit Jalil, Kuala Lumpur 57000, Malaysia

E-mail: chye_soimoi@imu.edu.my

Key words: Schwann cells, melatonin, peripheral nerve injury, glial cell-derived neurotrophic factor, Ras/Raf/ERK, MAPK
Previous studies have suggested that Schwann cells are important in the regeneration of peripheral axons and functional recovery $(3,4)$. After the events of a PNI, mature Schwann cells dedifferentiate into progenitor-like Schwann cells, known as Schwann cell precursors, promote myelin debris clearance and tubular reconstruction, and also form a cellular bridge spanning the gap between ends of damaged nerves $(5,6)$. Subsequently, Schwann cell precursors secrete neurotrophic factors to enhance Schwann cell proliferation and can lead to the formation of Bunger bands (6-8).

The Ras/Raf/ERK signaling pathway plays an important role in Schwann cell dedifferentiation (9). Previous studies have demonstrated that Ras/Raf/ERK activation results in cell cycle arrest of primary neurons and promotes differentiation $(9,10)$. Additionally, ERK has a role in regulating Wallerian degeneration and regeneration; sustained ERK activation is known to initiate cell proliferation (7). Glial cell-derived neurotropic factor (GDNF) is a survival factor that stimulates both peripheral regeneration and the functional recovery of several types of neurons (11-13). Previous studies have shown that GDNF transcription can be increased via the activation of the Schwann cell purinergic receptor, followed by the activation of protein kinase C (PKC) and protein kinase D (PKD) $(14,15)$. $\mathrm{PKD}$, originally characterized as an isoform of PKC, regulates proliferation, migration and differentiation of numerous cell types, and promotes neuron regeneration $(14,15)$.

Although microsurgical techniques have been introduced to repair PNI, in the past two decades only a small number of patients have regained full functional recovery (16). Therefore, it is important to search for new approaches that could promote nerve regeneration after PNI.

Melatonin is a hormone secreted by the pineal gland. Previous studies have demonstrated that melatonin stimulates the proliferation of avian astrocytes, dentate neurons and hippocampal neurons $(17,18)$. The action of melatonin is mediated through a receptor-dependent signaling pathway (19). Additionally, melatonin has free radical scavenging and antioxidant properties, which can decrease malondialdehyde levels and may reverse the ischemia-reperfusion injury of the sciatic nerve (12). In the present study, the effects of melatonin and the molecular mechanism involved in promoting the proliferation 
of Schwann cells were investigated. A better understanding of the molecular mechanism of melatonin-induced Schwann cell proliferation may provide important insight regarding the potential use of melatonin in improving nerve regeneration.

\section{Materials and methods}

Materials. Dulbecco's modified Eagle's medium (DMEM), fetal bovine serum (FBS), penicillin-streptomycin, EDTA were purchased from Gibco; Thermo Fisher Scientific, Inc. MTT, dimethyl sulfoxide, Triton X-100, Tergitol NP-40, Tris-HCl, PBS, dithiothreitol, SDS, ammonium acetate, Tris-borate-EDTA buffer, Bradford reagent and phenylmethyl sulfonyl fluoride were purchased from Sigma-Aldrich; Merck KGaA. Primary antibodies against SAPK-JNK (cat. no. 9926T), p38 (cat. no. 9926T), ERK (cat. no. 9926T), p-SAPK-JNK (cat. no. 9910T), p-p38 (cat. no. 9910T), p-ERK (cat. no. 9910T), Ras (cat. no. 18070T), c-Raf (cat. no. 9422T), p-c-Raf (cat. no. 9427S), b-Raf (cat. no. 9433S) and p-b-Raf (cat. no. 2696S), in addition to horseradish peroxidase-conjugated goat anti-rabbit (cat. no. 7074S) and anti-mouse (cat. no. 7076S) secondary antibodies were purchased from Cell Signaling Technology, Inc. Primary antibodies against MT1 (cat. no. sc-13177), MT2 (cat. no. sc-13186), PKC (cat. no. sc-10800), GDNF (cat. no. sc328) and $\alpha$-tubulin (cat. no. sc-8035) were purchased from Santa Cruz Biotechnology, Inc. Primary antibody against Sox 2 (cat. no. ab79351) and Alexa-Fluor ${ }^{\circledR} 488$-conjugated goat anti-mouse secondary antibody (cat. no. ab150117) were purchased from Abcam. Amersham ECL-Plus Western Blotting Reagents and PVDF membranes were obtained from GE Healthcare Life Sciences. RNeasy Mini kit and QuantiNova SYBR Green PCR kit were purchased from Qiagen, $\mathrm{GmbH}$.

Cell culture and treatment. RT4-D6P2T (RT4), a rat neural Schwann cell line, was purchased from The American Type Culture Collection and cultured in DMEM supplemented with $10 \%$ heat-inactivated FBS. The cells were maintained in incubator at $37^{\circ} \mathrm{C}$ with $5 \% \mathrm{CO}_{2}$. Melatonin stock concentration of $50 \mathrm{mg} / \mathrm{ml}(215.26 \mu \mathrm{M})$ was freshly prepared with ethanol.

Cell morphology. Schwann cells $\left(3 \times 10^{5}\right)$ were seeded into $35-\mathrm{mm}$ tissue culture dishes overnight. The cells were then treated with various concentrations of melatonin $(0.5-10 \mu \mathrm{M})$ dissolved in serum-free medium at $37^{\circ} \mathrm{C}$. After $24 \mathrm{~h}$ treatment, the morphological changes in the Schwann cells were observed using light microscopy (magnification, $\mathrm{x} 200$ ).

MTT assay. Cell proliferation was determined by an MTT assay. In total, $1 \times 10^{5}$ Schwann cells were seeded in a 96-well plate overnight. The cells were treated with melatonin concentrations of $0.5-10 \mu \mathrm{M}$ in serum-free medium. After $24 \mathrm{~h}$ of treatment, Schwann cells were added with MTT to a final concentration of $1 \mathrm{mg} / \mathrm{ml}$. After $3 \mathrm{~h}$ incubation, formazan crystals were dissolved using $100 \mu \mathrm{l}$ of DMSO and absorbance was measured using a microplate reader (Infinite 200 PRO; Tecan Group, Ltd.) at a wavelength of $570 \mathrm{~nm}$.

Immunofluorescence staining. Melatonin-induced Schwann cell dedifferentiation was demonstrated by Sox 2

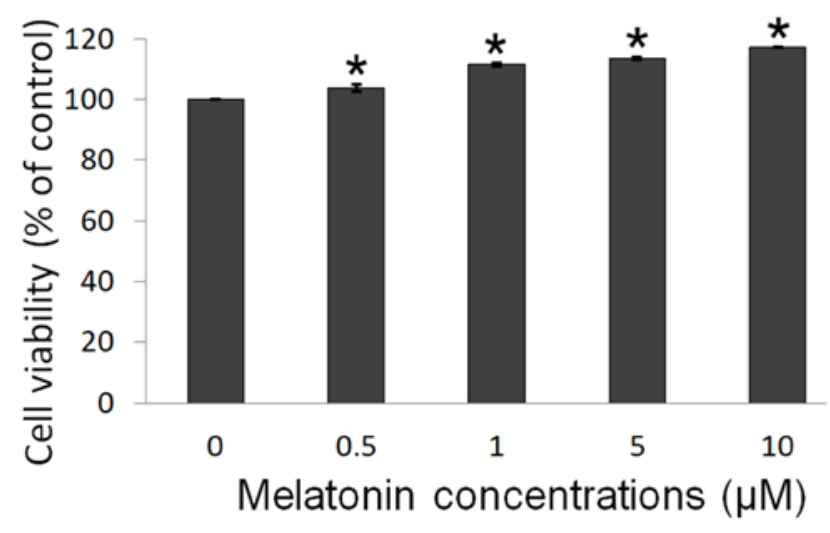

Figure 1. Melatonin increases proliferation of Schwann cells. Schwann cells were exposed to different concentrations of melatonin $(0.5,1,5$ and $10 \mu \mathrm{M})$ for $24 \mathrm{~h}$ and then examined for cell viability by an MTT assay. All data are presented as the mean \pm standard deviation. ${ }^{*} \mathrm{P}<0.05$ vs. the control.

immunofluorescence staining. Schwann cells were treated with melatonin $(1$ and $10 \mu \mathrm{M})$ in serum-free medium. After $24 \mathrm{~h}$ treatment, Schwann cells were fixed with $4 \%$ paraformaldehyde in PBS at $37^{\circ} \mathrm{C}$ for 30 min and blocked with $1 \%$ BSA (Sigma-Aldrich; Merck KGaA) for $1 \mathrm{~h}$ at $37^{\circ} \mathrm{C}$. The cells were then incubated with anti-Sox 2 antibody (1:50) overnight at $4^{\circ} \mathrm{C}$ followed by incubation with the AlexaFluor ${ }^{\circledR} 488$-conjugated antibodies (1:200 dilution) for $1 \mathrm{~h}$ at $37^{\circ} \mathrm{C}$. Primary and secondary antibodies were diluted in PBS. Cells were counterstained with $0.5 \mu \mathrm{g} / \mathrm{ml}$ DAPI (Invitrogen; Thermo Fisher Scientific, Inc.) diluted in PBS (1:500) for $15 \mathrm{~min}$ at $37^{\circ} \mathrm{C}$ and observed under a fluorescent microscope (magnification, x200).

Reverse transcription-quantitative PCR (RT-qPCR). Total RNA of melatonin-treated cells was extracted using the RNeasy Mini kit. The cells were homogenised with the RNeasy lysis buffer provided in the kit. RNA was collected with the RNeasy Mini spin column, according to the manufacturer's instruction. RNA ( $1 \mu \mathrm{g})$ was quantified at absorbance of $260 / 280 \mathrm{~nm}$ with a plate reader (Infinite ${ }^{\circledR} 200$ PRO NanoQuant; Tecan Group, Ltd.).

cDNA was synthesized using the Maxima First Strand cDNA Synthesis kit (Thermo Fisher Scientific, Inc.) according to manufacturer's protocol. The temperature protocol for reverse transcription was as follows: $2 \mathrm{~min}$ at $37^{\circ} \mathrm{C}, 10 \mathrm{~min}$ at $25^{\circ} \mathrm{C}$, $15 \mathrm{~min}$ at $50^{\circ} \mathrm{C}$ and $85^{\circ} \mathrm{C}$ for $5 \mathrm{~min}$. RT-qPCR was performed using QuantiNova SYBR Green PCR kit. The procedures followed the manufacturer's recommended amplification conditions with iQ5 real-time PCR detection system. The sequences of Rattus norvegicus primers used for the PCR were as follows: GAPDH-forward, 5'-TGCACCACCAACTGCTTAG-3' and reverse, 5'-GGATGCAGGGATGATGTTC-3'; MT1-forward, 5'-TCATCTTTACTATCGTGGTGG-3' and reverse, 5'ACC ACAAATATATTCCCTGCG-3'; MT2-forward, 5'-ACCTGT TACTGAATGTTGCC-3' and reverse, 5'-AACGAAGTCTCA CTTCAACAC-3'; GDNF-forward, 5'-TGACCAGTGACTCCA ATATG-3' and reverse, 5'-TACCTTGTCACTTGTTAGCC-3'; and PKC-forward, 5'-CCAAAAGCTAGAGACAAGCG-3' and reverse, 5'-TGGAATCTGCATTCACCTAC-3'. The thermocycling conditions were as follows: Initial denaturation $95^{\circ} \mathrm{C}$ for $2 \mathrm{~min}$, followed by 40 cycles of $95^{\circ} \mathrm{C}$ for $5 \mathrm{sec}$ and $60^{\circ} \mathrm{C}$ for 

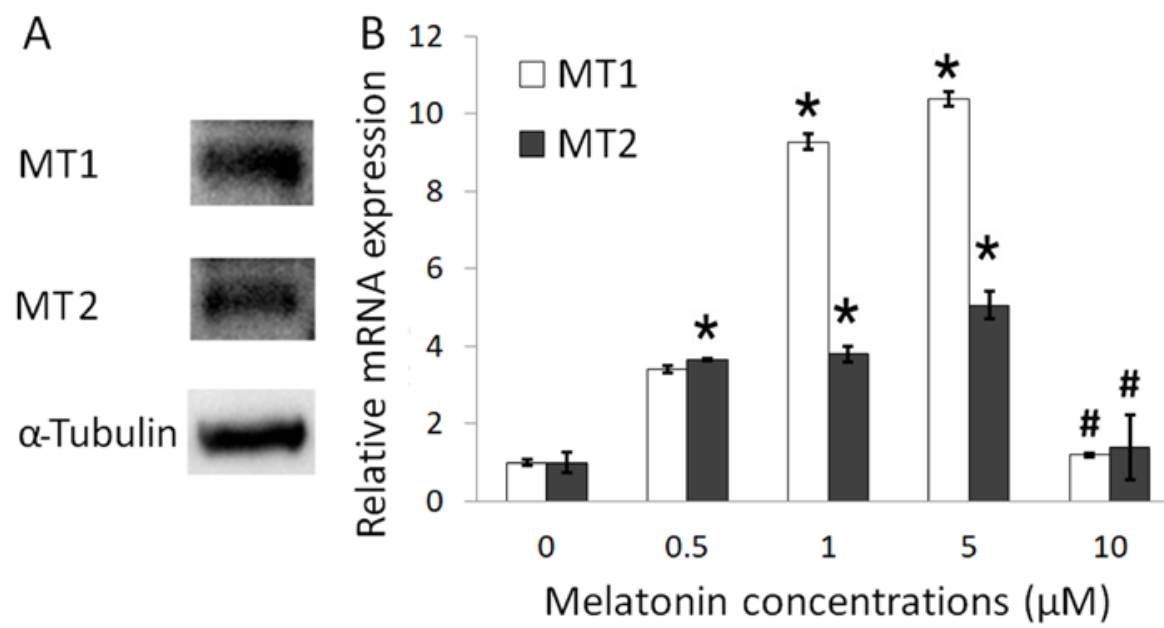

Figure 2. Protein and gene expressions of MT1 and MT2 in RT4 Schwann cells. (A) Both MT1 and MT2 proteins were expressed in RT4 Schwann cells. (B) MT1 and MT2 were significantly upregulated at lower concentrations $(0.5,1$ and $5 \mu \mathrm{M})$ of melatonin but not at a higher concentration $(10 \mu \mathrm{M})$. MT1 gene expression was higher than MT2 in RT4 Schwann cells. All data are presented as the mean \pm standard deviation. ${ }^{*} \mathrm{P}<0.05$ vs. respective control and ${ }^{\text {"}} \mathrm{P}<0.05$ vs. $0.5,1$ and $5 \mu \mathrm{M}$. RT4, RT4-D6P2T.

$10 \mathrm{sec}$. Relative mRNA expression of each gene to GAPDH was calculated based on the $2^{-\Delta \Delta \mathrm{Cq}}$ method (20).

Western blotting assay. Schwann cells treated with melatonin were lysed with 10X SDS sample buffer [62.5 mM Tris- $\mathrm{HCl}$ (pH 6.8), 2\% SDS, 10\% glycerol and 100 mM DTT]. Protein concentration was determined using the Quick Start ${ }^{\mathrm{TM}}$ Bradford Protein Assay kit (Bio-Rad Laboratories, Inc.). Protein samples $(25 \mu \mathrm{g})$ were applied to $10 \%$ gels and separated by SDS-PAGE and transferred to PVDF membranes. The membranes were blocked with 5\% BSA for $1 \mathrm{~h}$ at room temperature and then incubated with primary antibodies against MT1, MT2, GDNF, PKC, Ras, B-raf, p-B-Raf, C-raf, p-C-Raf, ERK1/2, p-ERK1/2, p39, p-p38, SAPK-JNK, p-SAPK-JNK and $\alpha$-tubulin at $4^{\circ} \mathrm{C}$ overnight. All primary antibodies were prepared in 1:500 dilutions in blocking buffer. The blots were then incubated with horseradish peroxidase-conjugated anti-rabbit/mouse secondary antibodies at 1:10,000 dilution for $1 \mathrm{~h}$ at room temperature. The blots were subsequently developed with SuperSignal $^{\mathrm{TM}}$ West Femto Maximum Sensitivity (Thermo Fisher Scientific, Inc.) substrate and visualised using ChemiDoc $\mathrm{XRS}^{+}$system (Bio-Rad Laboratories, Inc.). Quantitative blot data were analysed and calculated using Image Lab Software (version 4.0; Bio-Rad Laboratories, Inc.).

Statistical analysis. All experiments were repeated three times and data were presented as the mean \pm standard deviation. Statistical analysis was performed using one-way ANOVA followed by Dunnett's test (SPSS 21.0; IBM Corp.). $\mathrm{P}<0.05$ was considered to indicate a statistically significant difference.

\section{Results}

Melatonin enhances Schwann cell proliferation. An MTT assay was performed to determine the melatonin-induced proliferation of Schwann cells. The results showed that melatonin increases Schwann cell proliferation, after treatment with $0.5,1,5$ and $10 \mu \mathrm{M}$ melatonin (Fig. 1). The cell viability was significantly increased from 3.8 to $17.2 \%$ across the different treatment groups, suggesting that melatonin promoted Schwann cell proliferation in a dose-dependent manner.

Melatonin increases the gene expression of MT1 and MT2 receptors in Schwann cells. To determine the presence of melatonin receptors on Schwann cells, western blotting (Fig. 2A) and RT-qPCR (Fig. 2B) were performed. The present study identified the presence of both MT1 and MT2 receptors in Schwann cells. Following treatment with 1 and $5 \mu \mathrm{M}$ melatonin, the expression of MT1 and MT2 receptor mRNA were significantly increased compared with control. However, after treatment with $10 \mu \mathrm{M}$ melatonin, the expression of MT1 and MT2 receptor mRNA was significantly decreased compared with $0.5,1$ and $5 \mu \mathrm{M}$ melatonin treatment (Fig. 2B). MT1 gene expression was higher compared with MT2 following treatment with 1 and $5 \mu \mathrm{M}$ melatonin, suggesting that MT1 was more responsive to the melatonin treatment and may serve a role in inducing proliferation in Schwann cells.

Melatonin-induced Schwann cell dedifferentiation. To determine if dedifferentiation of Schwann cells was induced by melatonin, immunofluorescence staining and a western blotting assay were conducted. Under light microscope observation, Schwann cells have oval, spindle-shape or bipolar-like cell morphology. The cell morphology between control cells and melatonin-treated cells did not differ much (Fig. 3). Under fluorescent microscope observation, the cell nucleus was stained with DAPI (blue fluorescence). However, only melatonin-treated cells expressed the Sox 2 marker and showed green fluorescence (Fig. 3), which indicated a positive cell dedifferentiation process. Moreover, Sox 2 protein expression increased in a dose-dependent manner as shown by the western blotting assay (Fig. 4).

Melatonin increases GDNF and PKC protein expressions in Schwann cells. To determine GDNF and PKC gene and protein expressions in Schwann cells, RT-qPCR and western 


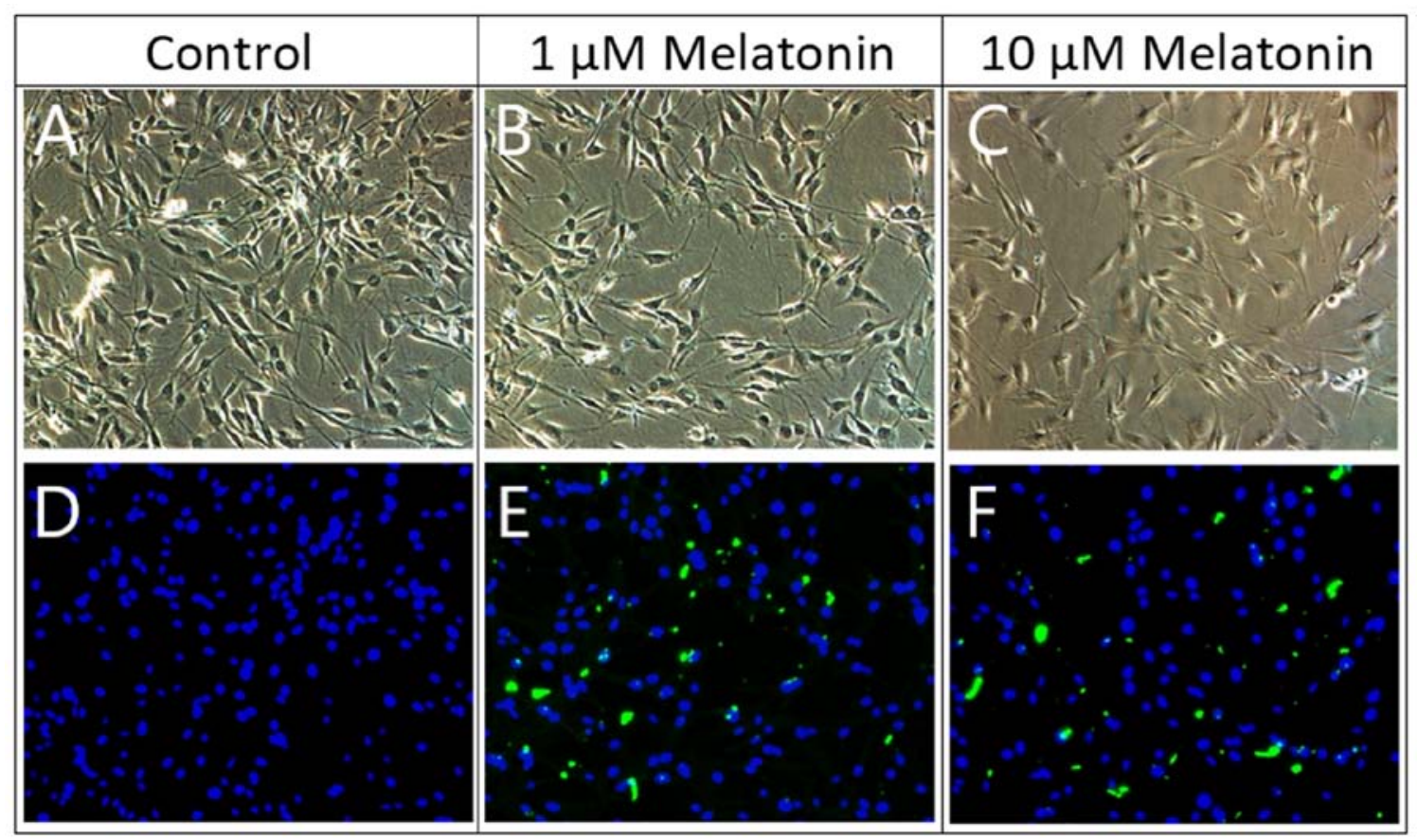

Figure 3. Melatonin induces Schwann cell dedifferentiation, as demonstrated by Sox 2 immunofluorescence staining. (A) Schwann cells were exposed to 0 (B) 1 and (C) $10 \mu \mathrm{M}$ melatonin for $24 \mathrm{~h}$ and then observed under a light microscope. (D) Schwann cells were exposed to 0 (E) 1 and (F) $10 \mu \mathrm{M}$ melatonin for $24 \mathrm{~h}$, following which immunofluorescence staining was performed for observation under a fluorescent microscope. Magnification, x200.

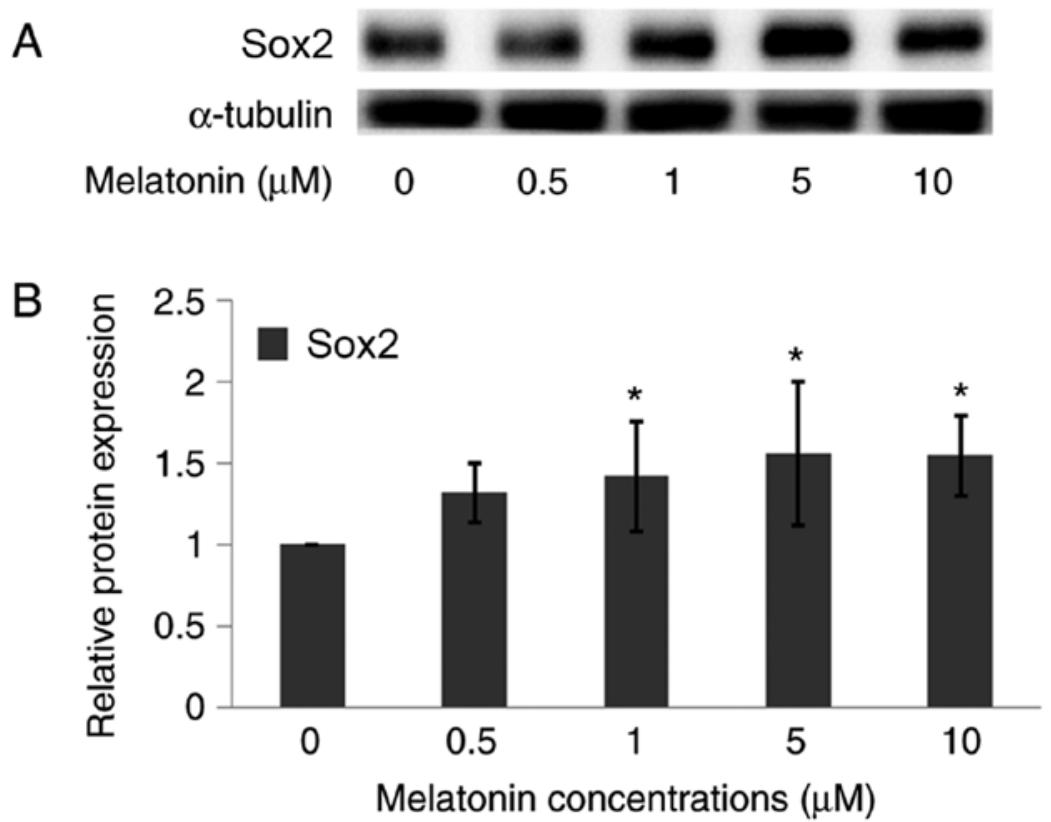

Figure 4. Protein expression of Sox 2 in RT4-D6P2T Schwann cells after melatonin treatment. (A) Western blot analysis shows that melatonin upregulated Sox2 protein expression. (B) Relative protein fold compared with the control was quantified using Image Lab software and $\alpha$-tubulin was used as the housekeeping gene. All data are presented as the mean \pm standard deviation. ${ }^{*} \mathrm{P}<0.05$ vs. the control.

blotting assays were conducted. The GDNF protein expression was significantly upregulated when the cells were treated with 1, 5 and $10 \mu \mathrm{M}$ melatonin as compared with the control, whilst PKC protein expression was significantly upregulated following treatment with 1 and $5 \mu \mathrm{M}$ melatonin compared with control (Fig. 5A and B). RT-qPCR analysis showed that GDNF and PKC gene expressions were significantly upregulated in cells treated with 1 and $5 \mu \mathrm{M}$ melatonin as compared with the control (Fig. 5C).
Melatonin increases Ras and p-Raf protein expression in Schwann cells. The Ras, B-Raf, p-B-Raf C-Raf and p-C-Raf protein expressions in Schwann cells were measured by western blotting. In Fig. 6A, after melatonin treatment, the Ras, p-B-Raf and p-C-Raf protein expressions increased in a dose-dependent manner. However, there were no protein expressions changes for B-Raf and C-Raf. In Fig. 6B, the normalized phosphorylated protein was compared with the 
A

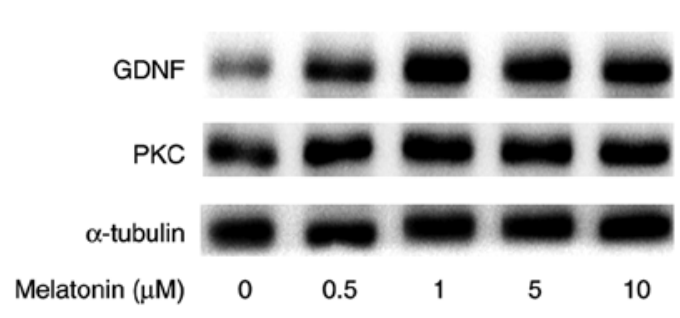

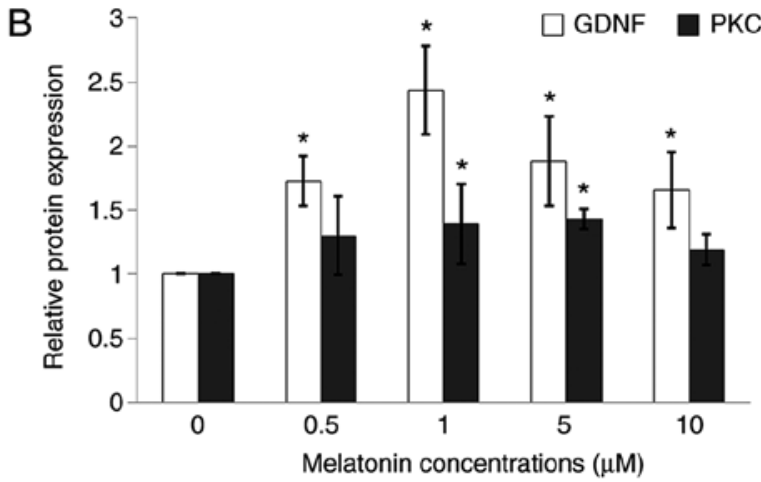

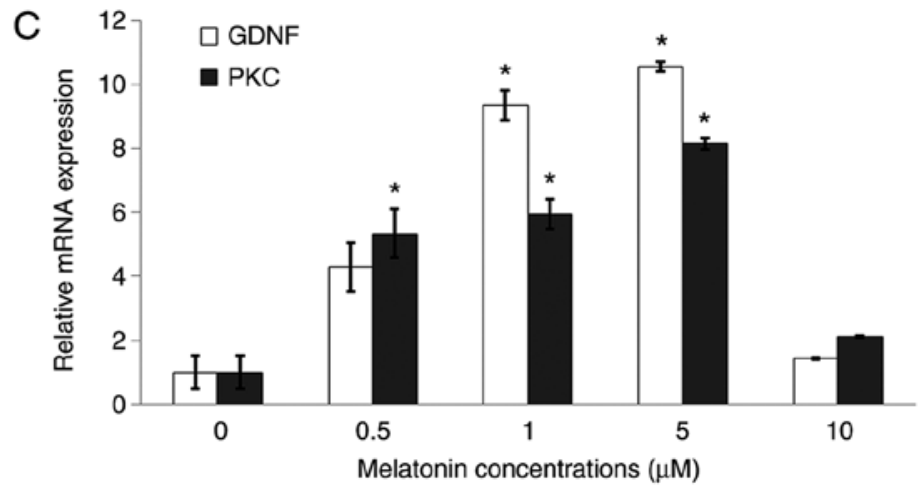

Figure 5. Protein and gene expressions of GDNF and PKC in RT4-D6P2T Schwann cells after melatonin treatment. (A) Western blot analysis shows that melatonin affected GDNF and PKC protein expressions. (B) Relative protein fold compared with the control was quantified using Image Lab software and $\alpha$-tubulin was used as the housekeeping gene. (C) Reverse transcription-quantitative PCR was performed to analyse gene expressions of GNDF and PKC. Both GDNF and PKC were upregulated after treatment with melatonin. All data are presented as the mean \pm standard deviation. ${ }^{*} \mathrm{P}<0.05$ vs. respective control. GDNF, glial cell-derived neurotropic factor; PKC, protein kinase C.

A

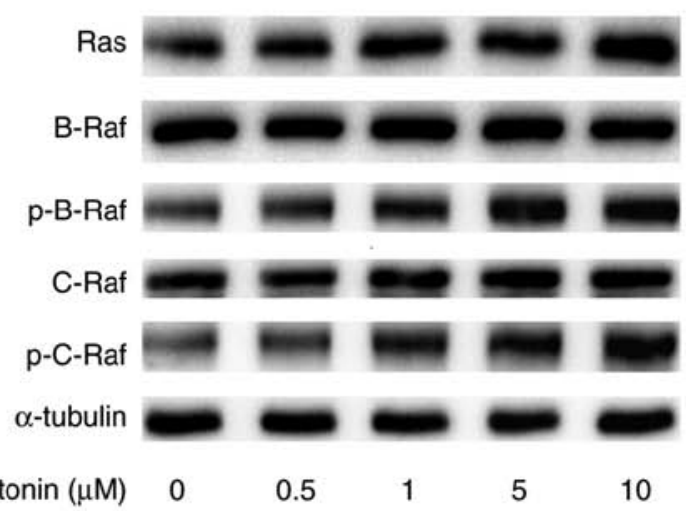

B

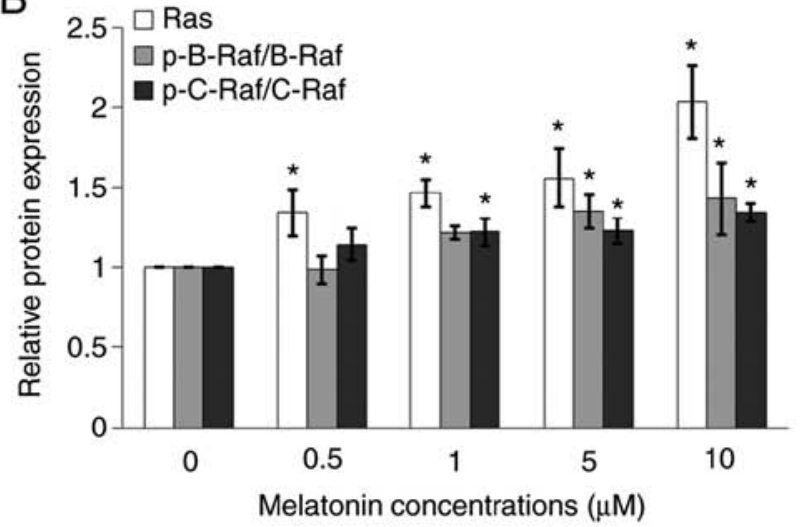

Figure 6. Protein expressions of the Ras/Raf/ERK pathway in RT4-D6P2T Schwann cells after melatonin treatment. (A) Western blot analysis shows that melatonin affected Ras, p-B-Raf and p-C-Raf protein expressions. (B) Relative protein fold compared with the control was quantified using Image Lab software and $\alpha$-tubulin was used as the housekeeping gene. All data are presented as the mean \pm standard deviation. ${ }^{*} \mathrm{P}<0.05$ vs. respective control. p, phosphorylated.

respective total protein, which showed that $\mathrm{p}-\mathrm{B}-\mathrm{Raf} / \mathrm{B}-\mathrm{Raf}$ and $\mathrm{p}$-C-Raf/C-Raf protein expressions increased in a dose-dependent manner, especially at higher concentrations of melatonin (5 and $10 \mu \mathrm{M})$.

Melatonin regulates ERK, SAPK-JNK and p38 protein expressions in Schwann cells. ERK, p-ERK, SAPK-JNK, p-SAPK-JNK, p38 and p-p38 protein expressions were measured in Schwann cells using a western blotting assay. The present study showed no significant difference in the expression of total protein levels of ERK, SAPK/JNK and p38 between the control and the melatonin treated groups (Fig. 7A). However, while normalized phosphorylated proteins with the respective total proteins, the results showed that in the melatonin treated groups, p-ERK(p44)/ERK(p44) and $\mathrm{p}-\mathrm{ERK}(\mathrm{p} 42) / \mathrm{ERK}(\mathrm{p} 42)$ increased in a dose-dependent 
A

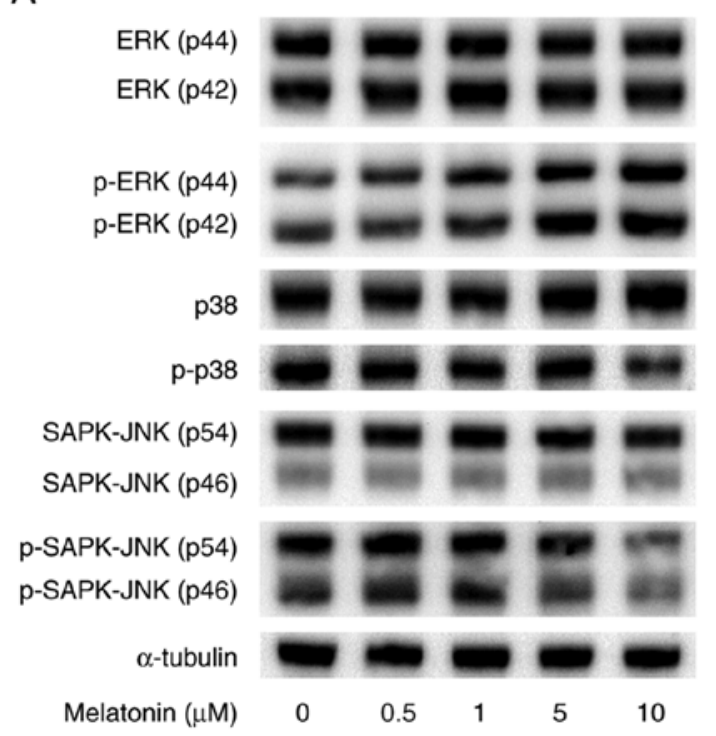

B

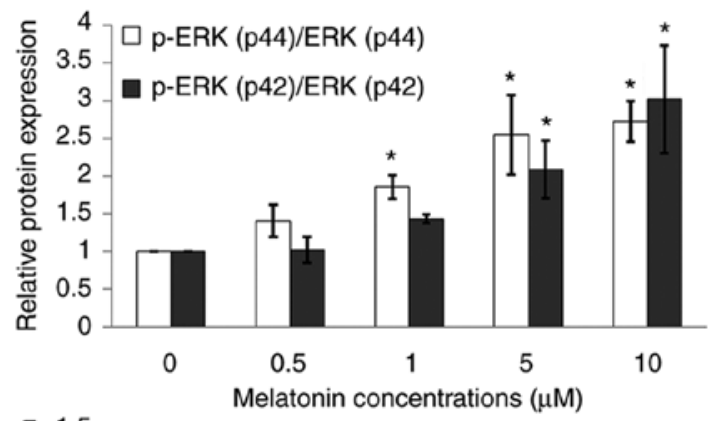

C

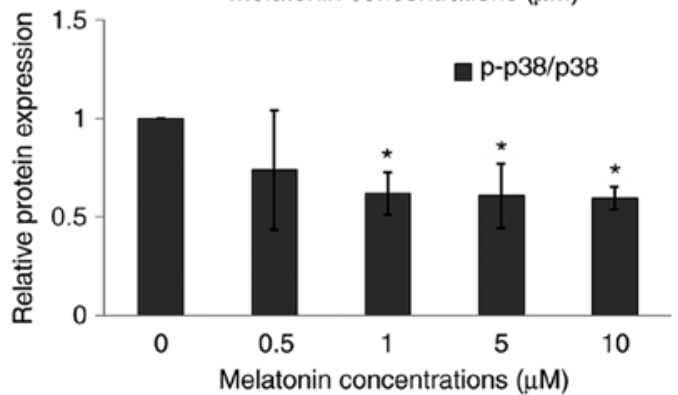

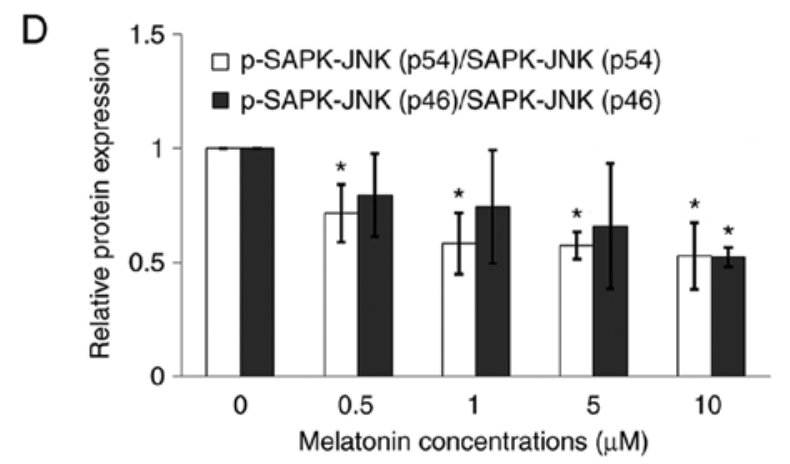

Figure 7. Protein expressions of the MAPK pathway in RT4-D6P2T Schwann cells after melatonin treatment. (A) Representative western blotting images showing the effects of melatonin treatment on ERK, p38 and SAPK-JNK phosphorylation in Schwann cells. (B) Quantitative comparison of relative ratios of p-ERK (p44)/ERK (p44) and p-ERK (42)/ERK (p42) in melatonin treated groups compared with control. (C) Quantitative comparison of relative ratios of p-p38/p38 in melatonin treated groups with control. (D) Quantitative comparison of relative ratios of p-SAPK-JNK (p54)/SAPK-JNK (p54) and p-SAPK-JNK (p46)/SAPK-JNK (p46) in melatonin treated groups with control. All data are presented as the mean \pm standard deviation. "P<0.05 vs. respective control. p, phosphorylated.

manner (Fig. 7B), especially at higher concentrations of melatonin $(5$ and $10 \mu \mathrm{M})$. Furthermore, melatonin downregulated the expressions of p-SAPK-JNK(p54)/SAPK-JNK(p54), p-SAPK-JNK(p46)/SAPK-JNK(p46) (Fig. 7D) and p-p38/p38 (Fig. 7C) proteins as compared with the control.

\section{Discussion}

Melatonin has been shown to promote glial cell survival, axonal regeneration and neuronal stem cell proliferation $(21,22)$. Turgut et al (23) demonstrated that melatonin inhibited both collagen production and neuroma formation, resulting in axonal regeneration of the transected sciatic nerve in rats. In pinealectomized rats, melatonin suppressed transforming growth factor- $\beta$ and basic fibroblast growth factor protein expressions (24). The findings from a previous study suggested that melatonin could suppress collagen scar formation after PNI (23). Melatonin also increased the number of axons and the thickness of the myelin sheath after PNI (4). Stavisky et al (25) demonstrated that melatonin enhanced the repair of sciatic nerve crush injuries in rats. However, the exact molecular mechanism involved is not yet known.
Schwann cells play an important role in the regeneration of damaged nerves. Upon PNI, Schwann cells lose their connection to axons. This phenomenon triggers the continuous proliferation of Schwann cells and the formation of Bunger bands that provide guidance for axonal regeneration (5). The present study indicated that melatonin induced RT4 Schwann cell proliferation at concentrations of $0.5,1,5$ and $10 \mu \mathrm{M}$, while Chang et al (26) identified that the optimal melatonin concentrations to enhance RSC 96 Schwann cell proliferation were $0.1,1$ and $10 \mathrm{nM}$. This difference may be due to different cell lines being used in the previous study and melatonin having different efficacies in various cell lines. Moreover, Chang et al (26) also demonstrated that melatonin enhanced RSC 96 Schwann cell proliferation mainly via the MT1 receptor as well as phosphorylation of ERK1/2 protein expression. However, the present study not only suggested that melatonin is able to dedifferentiate RT4 Schwann cells, the present study also demonstrated that melatonin may enhance cell proliferation through three different pathways, which are the Ras/Raf/ERK, MAPK and GDNF/PKC pathways. The identification of these proliferation pathways could have important implications for future development of therapeutic approaches. The present results demonstrated that melatonin induces Schwann cell proliferation 
via MT1 and MT2 receptors, and the MT1 receptor expression was higher than MT2. Previous studies demonstrated that MT1 activation is involved in proliferation, differentiation and firing in neuronal cells $(27,28)$. Chern et al $(29)$ observed that MT2 activation enhanced endogenous neurogenesis in rats. MT2 also played an important role in axonogenesis in in vivo and in vitro models (30). However, a previous study demonstrated that melatonin can induce cell proliferation in rat pancreatic stellate cells, independent of MT1/MT2 receptor activations via the MAPK pathway (31). In the present study, following treatment with 1 and $5 \mu \mathrm{M}$ melatonin, the expression of MT1 and MT2 receptor mRNA were significantly increased compared with control. However, after treatment with $10 \mu \mathrm{M}$ melatonin, the expression of MT1 and MT2 receptor mRNA was reduced compared with $0.5,1$ and $5 \mu \mathrm{M}$ melatonin treatment. This means high concentrations of melatonin may not result in a high responses due to negative feedback effects that altered melatonin receptor or the saturation of melatonin receptors (32).

After PNI, Schwann cells upregulate inflammatory cytokines [tumour necrosis factor- $\alpha$, interleukin (IL)-1 $\alpha$, IL-6, IL-1 $\beta$, leukaemia inhibitory factor and monocyte chemotactic protein 1] production in the distal stump $(33,34)$. IL-6 and leukaemia inhibitory factor attract macrophages to the injured nerve and act on neurons to promote axonal regeneration $(35,36)$. Macrophages co-operate with the Schwann cells to degrade myelin debris that potentially inhibit axon growth (37). Macrophages also produce cytokines to promote vascularisation of the distal nerve $(38,39)$. Specifically, upregulation of neurotrophic factors (GDNF, artemin, brain-derived neurotrophic factor, neurotrophin-3, nerve growth factor and vascular endothelial growth factor) promote axonal elongation and the survival of injured neurons $(40,41)$. The present study identified the involvement of GDNF and PKC in the melatonin-mediated Schwann cell proliferation. Loss of GNDF signaling is one of the features of PNI, especially at the distal stump of injured sciatic nerves (42). Previous studies demonstrated that GDNF is a survival factor for several types of neurons (43-45). The addition of exogenous GDNF has been shown to improve peripheral nerve regeneration and functional recovery (46). The present study showed that GDNF was highly expressed in the melatonin-treated Schwann cells. A previous study has reported that Schwann cells secrete a range of neurotrophic factors, including GDNF, which have been shown to be involved in promoting the development and maintenance of a subset of dorsal root ganglion sensory neurons (11). Increased PKC protein expression was also observed in the present study. PKC phosphorylation is involved in the formation of the growth cone after neuronal injury, which is an important step for neuronal regeneration $(47,48)$. Therefore, the present data supported the hypothesis that melatonin promotes Schwann cell proliferation through the activation of the GDNF/PKC pathway.

Activation of the Ras/Raf/ERK signaling pathway is an important process in the development of Schwann cell-derived tumours $(9,49)$. Harrisingh et al (9) identified that the continuous activation of the Ras/Raf/ERK signaling pathway is able to induce Schwann cell dedifferentiation and proliferation. The present results demonstrated that melatonin induced increases in Ras, p-C-Raf/C-Raf, p-B-Raf/B-Raf, p-ERK $(\mathrm{p} 44) / \mathrm{ERK}(\mathrm{p} 44)$ and $\mathrm{p}-\mathrm{ERK}(\mathrm{p} 42) / \mathrm{ERK}(\mathrm{p} 42)$ protein expressions in a dose-dependent manner. There are three different Raf isoforms (Raf-1/C-Raf, B-Raf and A-Raf), which consist of three conserved regions (CR; CR1, CR2 and CR3) (50). CR1 consists of a Ras binding domain and a cysteine rich domain (51). CR2 consists of activating phosphorylation and inhibitory sites, which regulate Ras binding and Raf activation (52). CR3 consists of a kinase activation domain (53). The major differences between the three Raf isoforms are dependent on the number and location of activating phosphorylation, inhibitory and autophosphorylation sites $(54,55)$. All Raf proteins share MEK1/2 kinases as substrates (56). MEK1/2 in turn activates ERK1/2, and this pathway regulates cell proliferation and differentiation $(50,57)$. p-ERK (p44) and p-ERK (p42) proteins are rapidly phosphorylated in response to all mitogens and are ubiquitously expressed; there are no obvious regulatory differences inferred from their protein sequences, their regulation or their sub-cellular localization (49). With Schwann cells being dedifferentiated to Schwann cell precursors, the proliferation rate was enhanced in the presence of cAMP (10). Other previous studies have demonstrated that Ras/Raf/ERK signaling activation also drives the demyelination of peripheral nerves, and the Schwann cells remain in dedifferentiated states, which ultimately leads to axon regeneration and tubular reconstruction $(9,58)$.

MAPKs, consisting of ERK, SAPK-JNK, and p38 MAPKs, are all activated in Schwann cells after PNI (50). Previous studies suggested that the ERK pathway seems to play a more distinct role in Schwann cell dedifferentiation than the SAPK-JNK and p38 MAPK pathways $(59,60)$. The present results demonstrated that after melatonin treatment, p-ERK(44)/ERK(44) and p-ERK(42)/ERK(42) protein expressions increased in a dose-dependent manner. However, p-SAPK-JNK(p54)/SAPK-JNK(p54), p-SAPK-JNK(p46)/ SAPK-JNK(p46), p-p38/p38 ratio decreased in manner that is negatively associated with the dose of melatonin concentration used. In conclusion, the ERK pathway plays a more important role than the SAPK-JNK and p38 MAP kinase pathways in Schwann cell dedifferentiation. In summary, the present study provided evidence that melatonin promotes Schwann cell dedifferentiation and proliferation through the GDNF/PKC, Ras/Raf/ERK and MAPK pathways. Schwann cell proliferation plays a crucial role in PNI; the present study suggested the use of melatonin as a therapeutic agent to enhance recovery from PNI. In the future, the present results (melatonin concentrations and mechanisms involved) could be applied to treat sciatic nerve injury and pinealectomized rats to determine optimal melatonin concentrations and parameters for progress in functional recovery.

\section{Acknowledgements}

Not applicable.

\section{Funding}

The present study was funded by The Malaysia Toray Science Foundation (grant no. 14/G72).

\section{Availability of data and materials}

All data generated or analysed during the present study are included in this published article. 


\section{Authors' contributions}

YLT performed the experiments, data analysis and interpretation. GP performed the RT-qPCR, western blotting, data analysis and critical revision of the manuscript. RYK and KYN conceived and designed the study. SMC designed the study, wrote the original draft, edited and critically revised the manuscript. All authors read and approved the final manuscript.

\section{Ethics approval and consent to participate}

Not applicable.

\section{Patient consent for publication}

Not applicable.

\section{Competing interests}

The authors declare that they have no competing interests.

\section{References}

1. Ciaramitaro P, Mondelli M, Logullo F, Grimaldi S, Battiston B, Sard A, Scarinzi C, Migliaretti G, Faccani G and Cocito D Italian Network for Traumatic Neuropathies: Traumatic peripheral nerve injuries: Epidemiological findings, neuropathic pain and quality of life in 158 patients. J Peripher Nerv Syst 15: 120-127, 2010.

2. Richardson PM and Issa VM: Peripheral injury enhances central regeneration of primary sensory neurones. Nature 309: 791-793, 1984.

3. Fex Svennigsen A and Dahlin LB: Repair of the peripheral nerve-remyelination that works. Brain Sci 3: 1182-1197, 2013.

4. Aktas A, Turgut M, Kaplan S, Ulkay B, Odacı E, Akyüz O, Çolakoğlu S, Yazıcı AC and İnce O: The effect of intrauterine acute ethanol exposure on developing sciatic nerves and their myelination: A stereological study. J Exp Clin Med 26: 35-41, 2009.

5. Mirsky R, Jessen KR, Brennan A, Parkinson D, Dong Z, Meier C, Parmantier E and Lawson D: Schwann cells as regulators of nerve development. J Physiol Paris 96: 17-24, 2002.

6. Naidu M and David P: Major cellular events in peripheral nerve regeneration. A brief overview. Int Med J 8: 69-72, 2009.

7. Agthong S, Kaewsema A, Tanomsridejchai $\mathrm{N}$ and Chentanez V: Activation of MAPK ERK in peripheral nerve after injury. BMC Neurosci 7: 45, 2006.

8. Barras FM, Pasche P, Bouche N, Aebischer P and Zurn AD: Glial cell line-derived neurotrophic factor released by synthetic guidance channels promotes facial nerve regeneration in the rat. J Neurosci Res 70: 746-755, 2002.

9. Harrisingh MC, Perez-Nadales E, Parkinson DB, Malcolm DS, Mudge AW and Lloyd AC: The Ras/Raf/ERK signalling pathway drives Schwann cell dedifferentiation. EMBO J 23: 3061-3071,2004

10. Ridley AJ, Paterson HF, Noble M and Land H: Ras-mediated cell cycle arrest is altered by nuclear oncogenes to induce Schwann cell transformation. EMBO J 7: 1635-1645, 1988.

11. Höke A, Ho T, Crawford TO, LeBel C, Hilt D and Griffin JW: Glial cell line-derived neurotrophic factor alters axon Schwann cell units and promotes myelination in unmyelinated nerve fibers. J Neurosci 23: 561-567, 2003.

12. Sayan H, Ozacmak VH, Ozen OA, Coskun O, Arslan SO, Sezen SC and Aktas RG: Beneficial effects of melatonin on reperfusion injury in rat sciatic nerve. J Pineal Res 37: 143-148, 2004.

13. Piirsoo M, Kaljas A, Tamm K and Timmusk T: Expression of NGF and GDNF family members and their receptors during peripheral nerve development and differentiation of Schwann cells in vitro. Neurosci Lett 469: 135-140, 2010.

14. Xu P, Rosen KM, Hedstrom K, Rey O, Guha S, Hart C and Corfas G: Nerve injury induces glial cell line-derived neurotrophic factor (GDNF) expression in Schwann cells through purinergic signaling and the PKC-PKD pathway. Glia 61: 1029-1040, 20131.
15. Svensson K, Zeidman R, Trollér U, Schultz A and Larsson C: Protein Kinase $\mathrm{C}$ betal is implicated in the regulation of neuroblastoma cell growth and proliferation. Cell Growth Differ 11: 641-648, 2000.

16. Martins RS, Bastos D, Siqueira MG, Heise CO and Teixeira MJ: Traumatic injuries of peripheral nerves: A review with emphasis on surgical indication. Arq Neuropsiquiatr 71: 811-814, 2013.

17. Ramirez-Rodriguez G, Klempin F, Babu H, Benítez-King G and Kempermann G: Melatonin modulates cell survival of new neurons in the hippocampus of adult mice. Neuropsychopharmacology 34: 2180-2191, 2009.

18. Rennie K, De Butte M and Pappas BA: Melatonin promotes neurogenesis in dentate gyrus in the pinealectomized rat. J Pineal Res 47: 313-317, 2009.

19. Fredrich M, Christ E and Korf HW: Differential regulation of cell proliferation and apoptosis by melatonin receptor subtype-signaling in the adult murine brain. Neuroendocrinology 107: 158-166, 2018.

20. Livak KJ and Schmittgen TD: Analysis of relative gene expression data using real-time quantitative PCR and the 2(-Delta Delta C(T)) method. Methods 25: 402-408, 2001.

21. Borlongan CV, Yamamoto $M$, Takei N, Kumazaki M, Ungsuparkorn C, Hida H, Sanberg PR and Nishino H: Glial cell survival is enhanced during melatonin-induced neuroprotection against cerebral ischemia. FASEB J 4: 1307-1317, 2000.

22. Kong PJ, Byun JS, Lim SY, Lee JJ, Hong SJ, Kwon KJ and Kim SS: Melatonin induces AKt phosphorylation through melatonin receptor- and PI3K-dependent pathways in primary astrocytes. Korean J Physiol Pharmacol 12: 37-41, 2008.

23. Turgut M, Uyanikgil Y, Baka M, Tunc AT, Yavapodlu A, Yurtseven ME and Kaplan S: Pinealectomy exaggerates and melatonin treatment suppresses neuroma formation of transected sciatic nerve in rats: Gross morphological, histological and stereoligical analysis. J Pineal Res 38: 284-291, 2005.

24. Turgut M, Oktem G, Uysal A and Yurtseven ME: Immunohistochemical profile of transforming growth factor-betal and basic fibroblast growth factor in sciatic nerve anastomosis following pinealectomy and exogenous melatonin administration in rats. J Clin Neurosci 13: 753-758, 2006.

25. Stavisky RC, Britt JM, Zuzek A, Truong E and Bittner GD: Melatonin enhances the in vitro and in vivo repair of severed rat sciatic axons. Neurosci Lett 376: 98-101, 2005.

26. Chang HM, Liu CH, Hsu WM, Chen LY, Wang HP, Wu TH, Chen KY, Ho WH and Liao WC: Proliferative effects of melatonin on Schwann cells: Implication for nerve regeneration following peripheral nerve injury. J Pineal Res 56: 322-332, 2014.

27. Dubocovich ML and Markowska M: Functional MT1 and MT2 melatonin receptors in mammals. Endocrine 27: 101-110, 2005.

28. Kaneko Y, Hayashi T, Yu S, Tajiri N, Bae EC, Solomita MA, Chheda SH, Weinbren NL, Parolini O and Borlongan CV: Human amniotic epithelial cells express melatonin receptor MT1, but not melatonin receptor MT2: A new perspective to neuroprotection. J Pineal Res 50: 272-280, 2011.

29. Chern CM, Liao JF, Wang YH and Shen YC: Melatonin ameliorates neural function by promoting endogenous neurogenesis through the MT2 melatonin receptor in ischemic-stroke mice. Free Radic Biol Med 52: 1634-1647, 2012.

30. Liu D, Wei N, Man HY, Lu Y, Zhu LQ and Wang JZ: The MT2 receptor stimulates axonogenesis and enhances synaptic transmission by activating Akt signalling. Cell Death Differ 22: 583-596, 2015

31. Santofimia-Castaño P, Garcia-Sanchez L, Ruy DC, Sanchez-Correa B, Fernandez-Bermejo M, Tarazona R, Salido GM and Gonzalez A: Melatonin induces calcium mobilization and influences cell proliferation independently of MT1/MT2 receptor activation in rat pancreatic stellate cells. Cell Biol Toxicol 31: 95-110, 2015.

32. Yu GD, Rusak B and Piggins HD: Regulation of melatonin-sensitivity and firing-rate rhythms of hamster suprachiasmatic nucleus neurons: Constant light effects. Brain Res 602: 191-199, 1993.

33. Martini R, Fischer S, López-Vales R and David S: Interactions between Schwann cells and macrophages in injury and inherited demyelinating disease. Glia 56: 566-1577, 2008.

34. Rotshenker S: Wallerian degeneration: The innate-immune response to traumatic nerve injury. J Neuroinflammation 8: 109, 2011.

35. Hirota $\mathrm{H}$, Kiyama $\mathrm{H}$, Kishimoto $\mathrm{T}$ and Taga $\mathrm{T}$ : Accelerated nerve regeneration in mice by upregulated expression of interleukin (IL) 6 and IL-6 receptor after trauma. J ExpMed 183: 2627-2634, 1996. 
36. Cafferty WB, Gardiner NJ, Gavazzi I, Powell J, McMahon SB, Heath JK, Munson J, Cohen J and Thompson SW: Leukemia inhibitory factor determines the growth status of injured adult sensory neurons. J Neurosci 21: 7161-7170, 2001.

37. Hirata K and Kawabuchi M: Myelin phagocytosis by macrophages and nonmacrophages during Wallerian degeneration. Microsc Res Tech 57: 541-547, 2002.

38. Barrette B, Hébert MA, Filali M, Lafortune K, Valli'eres N, Gowing G, Julien JP and Lacroix S: Requirement of myeloid cells for axon regeneration. J Neurosci 28: 9363-9376, 2008.

39. Cattin AL, Burden JJ, Van Emmenis L, Mackenzie FE, Hoving JJ, Garcia Calavia N, Guo Y, McLaughlin M, Rosenberg LH, Quereda V, et al: Macrophage-induced blood vessels guide Schwann cell-mediated regeneration of peripheral nerves. Cell 162: 1127-1139, 2015.

40. Wood MD and Mackinnon SE: Pathways regulating modality-specific axonal regeneration in peripheral nerve. Exp Neurol 265: 171-175, 2015.

41. Boyd JG and Gordon T: Neurotrophic factors and their receptors in axonal regeneration and functional recovery after peripheral nerve injury. Mol Neurobiol 27: 277-324, 2003.

42. Shi JY, Liu GS, Liu LF, Kuo SM, Ton CH, Wen ZH, Tee R, Chen $\mathrm{CH}$, Huang HT, Chen CL, et al: Glial cell line-derived neurotrophic factor gene transfer exerts protective effect on axons in sciatic nerve following constriction-induced peripheral nerve injury. Hum Gene Ther 22: 721-731, 2011.

43. Pascual A, Hidalgo-Figueroa M,Piruat JI,Pintado CO, Gómez-Díaz R and López-Barneo J: Absolute requirement of GDNF for adult catecholaminergic neuron survival. Nat Neurosci 11: 755-761, 2008.

44. Ortiz-Ortiz MA, Morán JM, Ruiz-Mesa LM, Bonmatty RG and Fuentes JM: Protective effect of the glial cell line-derived neurotrophic factor (GDNF) on human mesencephalic neuron-derived cells against neurotoxicity induced by paraquat. Environ Toxicol Pharmacol 31: 129-136, 2011

45. Meka DP, Müller-Rischart AK, Nidadavolu P, Mohammadi B, Motori E, Ponna SK, Aboutalebi H, Bassal M, Annamneedi A, Finckh B, et al: Parkin cooperates with GDNF/RET signaling to prevent dopaminergic neuron degeneration. J Clin Invest 125 : $1873-1885,2015$

46. Chen ZY, Cao L, Lu CL, He C and Bao X: Protective effect of exogenous glial cell line derived neurotrophic factor on neurons after sciatic nerve injury in rats. Sheng Li Xue Bao 52: 295-300, 2000 (In Chinese).

47. Kawakami T, Kawakami Y and Kitaura J: Protein kinase $\mathrm{C}$ beta (PKC beta): Normal functions and diseases. J Biochem 132 677-682, 2002.

48. Spinsanti P, De Vita T, Caruso A, Melchiorri D, Misasi R, Caricasole A and Nicoletti F: Differential activation of the calcium/protein kinase $\mathrm{C}$ and the canonical beta-catenin pathway by Wnt1 and Wnt7a produces opposite effects on cell proliferation in PC12 cells. J Neurochem 104: 1588-1598, 2008.
49. Buscà R, Pouysségur J and Lenormand P: ERK1 and ERK2 map kinases: Specific roles or functional redundancy? Front Cell Dev Biol 4: 53, 2016.

50. Leicht DT, Balan V, Kaplun A, Singh-Gupta V, Kaplun L, Dobson $M$ and Tzivion G: Raf kinases: Function, regulation and role in human cancer. Biochim Biophys Acta 1773: 1196-1212, 2007.

51. Tran NH, Wu X and Frost JA: B-Raf and Raf-1 are regulated by distinct autoregulatory mechanisms. J Biol Chem 280: 16244-16253, 2005.

52. Dhillon AS, Meikle S, Yazici Z, Eulitz M and Kolch W: Regulation of Raf-1 activation and signaling by dephosphorylation. EMBO J 21: 64-71, 2002.

53. Chong H, Lee J and Guan KL: Positive and negative regulation of Raf kinase activity and function by phosphorylation. EMBO J 20: 3716-3727, 2001.

54. Morrison DK, Heidecker G, Rapp UR and Copeland TD: Identification of the major phosphorylation sites of the Raf-1 kinase. J Biol Chem 268: 17309-17316, 1993.

55. Stephens RM, Sithanandam G, Copeland TD, Kaplan DR, Rapp UR and Morrison DK: 95-kilodalton B-Raf serine/threonine kinase: Identification of the protein and its major autophosphorylation site. Mol Cell Biol 12: 3733-3742, 1992.

56. Matallanas D, Birtwistle M, Romano D, Zebisch A, Rauch J, von Kriegsheim A and Kolch W: Raf family kinases: Old dogs have learned new tricks. Genes Cancer 2: 232-260, 2011.

57. Wellbrock C, Karasarides M and Marais R: The RAF proteins take centre stage. Nat Rev Mol Cell Biol 5: 875-885, 2004.

58. Napoli I, Noon LA, Ribeiro S, Kerai AP, Parrinello S, Rosenberg LH, Collins MJ, Harrisingh MC, White IJ, Woodhoo A and Lloyd AC: A central role for the ERK-signaling pathway in controlling Schwann cell plasticity and peripheral nerve regeneration in vivo. Neuron 73: 729-742, 2012.

59. Lee HJ, Shin YK and Park HT: Mitogen activated protein kinase family proteins and c-jun signaling in injury-induced Schwann cell plasticity. Exp Neurobiol 23: 130-137, 2014.

60. Shin YK, Jang SY, Park JY, Park SY, Lee HJ, Suh DJ and Park HT: The Neuregulin-Rac-MKK7 pathway regulates antagonistic c-jun/Krox20 expression in Schwann cell dedifferentiation. Glia 61: 892-904, 2013.

This work is licensed under a Creative Commons Attribution-NonCommercial-NoDerivatives 4.0 International (CC BY-NC-ND 4.0) License. 